\title{
CHALLENGES AND PROBLEMS OF FOOD PRODUCERS IN THE CONDITIONS OF THE COVID 19 VIRUS PANDEMIC
}

\section{Aleksandar Lukić ${ }^{1}$, Dragan Bulatović ${ }^{2}$, Dalibor Misirača ${ }^{3}$}

123 College "Academy of Business Economics", Čačak

Corresponding: aleksandarlukic.info@gmail.com ${ }^{1}$

Review article

Received: 10.04.2021; Accepted: 11.06.2021

\begin{abstract}
The current pandemic of the COVID-19 virus will cause great consequences for the overall world economy. The global pandemic requires a global response and it is already clear that economic policy makers will need to implement significant targeted fiscal, monetary and social measures to help the affected population and economy. Within the framework of support measures for the economy, the focus should be on supporting the sectors most affected. The agri-food sector is one of the most endangered sectors of the economy, and for that very reason, the subject of this paper are the challenges and problems of food producers in the conditions of a pandemic.
\end{abstract}

Keywords: pandemic, COVID-19, food production, economic crisis, economic policy measures.

\section{Introduction}

In the context of the global health and economic crisis caused by the COVID-19 virus pandemic, the agri-food sector of all countries will suffer significant negative effects, which are reflected in falling pro- $^{-}$ duction and income, rising unemployment, rising illiquidity, falling living standards and rising poverty. Mitigating these consequences will require long-term action by the state and taking a series of economic policy measures related to the introduction of tax relief, raising the level of state spending and lowering interest rates. In these conditions, food producers will need significant financial support in the form of subsidies, preferential credit lines and grants in order to preserve production and prevent bankruptcy. 
Lukic A. et al., Challenges and Problems of Food Producers in the Conditions of the Covid 19 Virus Pandemic

Measures to be taken must be well planned, timely and adequate, and countries that adapt and respond in the right way to the years of recovery will have some development advantages.

\section{The role of the agro-food sector in the economic structure}

Food and nutrition are the basic human need and condition of existence. According to European Community Regulation No. 178/2002, food is defined as any substance or product that has been processed, partially processed or unprocessed for human consumption or can be expected to be used for human consumption. The human body creates its own substances from the food it ingests, which enables the construction of cells, their renewal and growth, that is, the maintenance of a normal body composition. In that sense, proper nutrition is a basic precondition for preserving and improving the health, not only of the individual, but also of the general population. [Barjaktarović Labović, 2018, 5]

Agriculture, as a part of the agrifood sector, is undoubtedly the oldest economic activity and the most important food producer. The agri-food sector consists of the so- $^{-}$ called farming and postfarming sector. The farming sector includes agriculture (farming, fruit growing, viticulture and livestock) and fishing, and the post-farming sector includes food production, beverage, animal feed and tobacco industries. This second sector is the sector of the food industry (agro-industry) and as a part of the processing industry includes the processing of agricultural products. Due to their interconnectedness, in the literature dealing with this issue, agriculture and the food industry are classified as a single agri-food sector. [Marković, 2017, 9]

The development of agriculture has a significant place in the economic development of most countries. At the same time, modern approaches to development are inconceivable without sustainability as an important segment of agricultural and food production. The result of every modernly organized agricultural production can be seen in the supply of the population with quality agricultural products, produced in a productive way, while the environment is maximally preserved through controlled production and technological processes. Today, modern agriculture is much more than the production of agricultural products. It is the raw material base of the food industry and an important supplier of trade and tourism. [Topić \& Spasojević, 2016, 111] 
The benefits of agriculture are diverse and the contribution to the development of the rural community increases the number of farms and employment, strengthens the local economy and preserves the rural culture. [Marković, 2017, 161]

In addition to agriculture, the food industry is an integral part of the agri-food sector. It is most often concentrated in larger centers of consumption and produces products of higher stages of processing. The support of agricultural and industrial policy is important for the development of the food industry. Agriculture and this part of the industry are interconnected. Just as the development of primary agricultural production affects the increase of utilization and development in the processing industry, so the strengthening of the food industry in turn encourages the development of agriculture.

\section{Food production in Serbia in the conditions of the COVID - 19 pandemic}

Since the beginning of the crisis caused by the COVID-19 pandemic, trade in agricultural and food products has shown greater resilience than trade in other products. The reasons for this are the significant income inelasticity of food demand due to its existential importance and the fact that most transport in trade in agricultural products (especially cereals and oilseeds) is done by ship, shipments that do not require large human interactions and are not severely affected by restrictions. pandemic.

The export of a larger number of agricultural products intended for food at the beginning of the pandemic in March 2020 increased compared to the same period of the previous year, while in the later period it recorded a certain decline. The initial growth in exports of agricultural products is the result of increased demand caused by the fear of a pandemic by consumers, but also the fact that the governments of many countries have intensified the processes of forming commodity reserves. Although the export of agricultural products was relatively stable, in the first quarter of 2020, exports from Asia decreased, and then in the following period, due to the spread of the COVID-19 pandemic, there was a decline in exports from Europe and North America. In contrast, Central and South America recorded significant export growth. [WTO, 2020, 9]

Figure 1 shows a comparative analysis of agricultural exports in 2019 and 2020 by regions in the world. 
Lukic A. et al., Challenges and Problems of Food Producers in the Conditions of the Covid 19 Virus Pandemic

Figure 1. Exports of agricultural products (\%)*

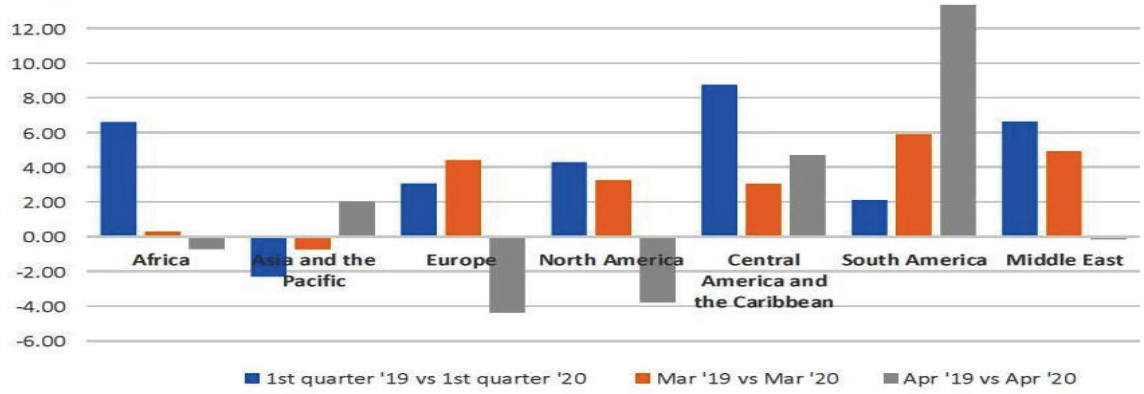

* Source: WTO Secretariat estimates

Imports of agricultural products later the demand for imports in during the first quarter of 2020, April was reduced compared to the and especially in March, increased previous year in Europe, North and for virtually all regions compared South America (Figure 2). to the same period in 2019, and

Figure 2. Imports of agricultural products (\%)*

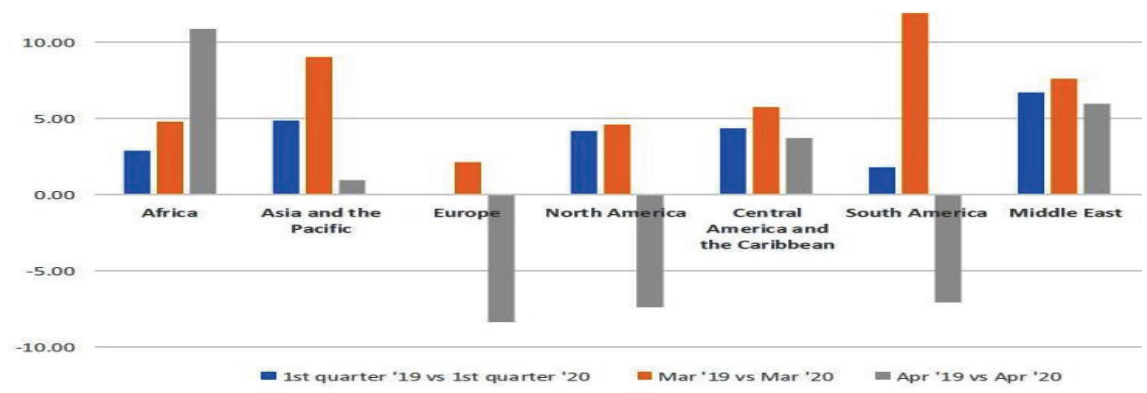

* Source:WTO Secretariat estimates

When it comes to the importance that agricultural production has for Serbia, it should be said that agriculture is far more than a sector of the economy that provides food security for citizens and a raw material base for the food industry. Agriculture directly contributes to the development of the food processing industry, but also to other activities such as tourism and trade, in the first place. It reduces the imbalance of the commodity balance, contributes to rural development, as well as economic and environmental balance.

Given the availability of significant natural and human resources, as well as the achieved level of production and processing, agricultural production is one of the most important economic activities in 
Serbia. This fact is supported by the data on the participation of agricultural production in the realization of gross domestic product. [Madžar, 2014, 127]

Compared to the average of EU countries, the Republic of Serbia has a significantly higher share of the agricultural sector in the total gross domestic product. The high share of agriculture in the basic macroeconomic aggregates of the Republic of Serbia in relation to other countries can be attributed on the one hand to rich natural resources and favorable climatic conditions for agricultural production, and on the other hand to the slower process of structural reform of the rest of the economy. Agricultural and food products play a significant role in the foreign trade of the Republic of Serbia, especially in exports. Their share in total exports has stabilized at around $23 \%$ in recent years. [Government of the Republic of Serbia, 2014, 8]

The share of agricultural production in the GDP of Serbia in recent years ranges between 6 and 7 percent. According to the share of agriculture in GDP, Serbia ranks fourth in Europe, and only the countries of the region - Albania, Northern Macedonia and Montenegro - have a larger share than it.

According to the data of the $\mathrm{Re}^{-}$ public Bureau of Statistics, agri- cultural production, hunting and service activities in January 2020, before the COVID-19 virus pandemic, generated export income in the amount of 85.3 million dollars. [Republic Statistical Office, 2020, 48]

The pandemic of the COVID-19 virus (SARS - CoV-2), which appeared in China at the end of 2019, caused great consequences for the entire world economy. Only ten years after the global economic crisis, the insufficiently recovered world economy is facing new temptations. Unlike the global crisis, which escalated in 2007 as a result of many years of accumulated structural problems, primarily in the financial sector, the "crown" crisis was not caused by economic causes. Just as the global crisis from the financial sector quickly spilled over into the real and scale sectors, causing longterm economic stagnation and debt crises in many countries, there is also a danger that the secondary effects of the "crown" crisis may last for a long time. [Institute of Economic Sciences, 2020, 1]

COVID-19 has already caused a significant economic crisis. From complete to partial or temporary shutdowns of factories, to supply chain disruptions, layoffs, liquidity crises and financial stresses, companies are already facing signifi- 
Lukic A. et al., Challenges and Problems of Food Producers in the Conditions of the Covid 19 Virus Pandemic

cant economic consequences. [Ernst \& Young, 2020, 2]

The current economic crisis has affected all countries of the world with varying intensity, regardless of the level of development and structure of the economy, all economic sectors and all social strata and individuals. The crisis has caused a decline in all macroeconomic aggregates and indicators in all countries of the world. The key consequences of the crisis are illiquidity, declining production and exports, rising unemployment, falling living standards and rising poverty. [Bošnjak, 2011, 4]

It is already obvious that the economic crisis caused by the pandemic will significantly affect the entire world economy and that agriculture will be one of the branches of the economy that will feel its consequences to the greatest extent. Producers no longer make the profits they rightly expect and seek state protection. It is becoming increasingly apparent that food production is a strategic area and requires special social treatment at a time of growing economic crisis. [Pejanović, 2011, 9]

The global financial and economic crisis will have a negative impact on the agricultural and food sector of the Republic of Serbia, especially through illiquidity, declining pro- duction, declining exports and imports and rising capital prices.

Since agriculture, along with other crisis-endangered economic activities (mining, manufacturing, construction, trade and transport), participates in the formation of GDP with over $50 \%$, it is clear that a significant decline in GDP in 2020 can be expected. in the second quarter of this year it was $6.4 \%$, while in the third quarter it was 1.3\%. [Republic Statistical Office, 2020]

For the sake of truth, it should be said that the crisis of agriculture in Serbia was not caused only by the pandemic of the COVID-19 virus, but that the causes of the crisis are numerous and refer to its permanently unfavorable economic position. The current crisis will only further emphasize the fact that less is invested in agriculture than is necessary and, consequently, less is gained from it than is possible. Natural potentials are insufficiently used, there is accelerated deagrarization and a low level of specialization in farm production. The equipment with modern machines is not at the required level, and the consumption of mineral fertilizers is insufficient, which results in reduced yields. The participation of individual agricultural farms and their symbolic organization into cooperatives is 
dominant. The level of slavery and production intensity is low and the fragmentation of holdings is pro- $^{-}$ nounced, among which farms up to three hectares dominate. [Pejanović, 2014, 29]

Based on the above, it is clear that the crisis in Serbian agriculture has been going on for a long time and that the development of agriculture is accompanied by chronic problems. The pandemic of the COVID-19 virus will further actualize the existing problems and will impose the need to take adequate systemic and continuous economic policy measures to overcome them.

The state and its institutions will play a key role in resolving the crisis. The view that the market can only solve the crisis without the intervention of the state and the institutional adjustment necessary to increase the efficiency and stability of the market and the quality of economic policy is unfounded. A market with sufficient and adequate regulation (regulated market) is a key precondition for overcoming the current global economic crisis. [Bosniak, 2011, 4]

The COVID-19 pandemic has provoked reactions combining expansive fiscal and monetary policies to alleviate the impending recession. These reactions are mostly related to the introduction of tax breaks, raising government spending and public borrowing (fiscal expansion), as well as lowering interest rates (monetary expansion). On average, the main focus of fiscal interventions is to help businesses in the form of tax breaks and security liquidity, while the goal of monetary policy is to provide cheap financing. In most cases, the main focus of fiscal interventions is on direct investments in the form of cash transfers, social assistance, job subsidies and infrastructure investments, but also on providing liquidity.

The Serbian government has announced a package of fiscal measures aimed at reducing the negative effects caused by the COVID19 pandemic, which prioritizes three sets of measures. The first set primarily refers to the postponement of payment of due tax liabilities, with repayment in installments, at the earliest from the beginning of 2021. The second set refers to direct assistance to entrepreneurs, micro, small and medium enterprises, as well as sub-sidies to large companies to maintain current employment levels. The third set aims to maintain the liquidity of economic entities through programs for granting loans and guarantee schemes to commercial banks to maintain liquidity and working capital of companies. The main motives of the proposed measures are to reduce the burden on economic 
Lukic A. et al., Challenges and Problems of Food Producers in the Conditions of the Covid 19 Virus Pandemic

entities, to amortize the decline of real variables and to stimulate demand. [Mikanović \& Kolar, 2020, 6]

In addition to the adopted measures, during the pandemic, a number of actions should be taken in order to reduce the negative consequences of the crisis on the functioning of the agri-food sector:

- Collective purchase centers should be created in which farmers will be able to sell their products without great mobility and receive an adequate amount of money for that;

- Farmers should be provided with subsidies, cash allowances and other forms of financing that will enable them to maintain their production;

- Conditions should be created for agricultural producers to offer the food they produce to the market in the form of electronic commerce;

- Agricultural loans should be reprogrammed, and the supply of farmers with energy and planting material should be provided in order for the works to be performed with quality and on time. [Torero Cullen, 2020, 2]

In addition, after the end of the pandemic in Serbian agriculture, a number of measures should be taken in order to mitigate the negative effects of the crisis and give the development of agriculture an $\mathrm{ex}^{-}$ pansive course:

- Overcoming the consequences of the crisis requires adjustments in all areas, including the agricultural industry. To get out of the crisis faster, it is necessary to stimulate the development of agriculture with subsidies and loans, as well as by investing in irrigation systems.

- A new concept of agricultural management based on the partnership role of the state and a regulated market is needed. The planning function of the state based on modern economic principles, following the example of developed countries, should be reaffirmed.

- Comprehensive reforms must ensure a satisfactory level and quality of agricultural production. It is necessary to reduce the cumbersome administration, organize advisory professional services, ensure transparent budget spending and control the spending of financial resources intended for agriculture.

- The budget rebalance should allocate a significantly higher amount of funds for the agricultural budget, in order to stop the negative trends and implement European projects of com- $^{-}$ 
petitiveness and rural development.

- Competitiveness in quality must be ensured by standardization and investments in new technologies and knowledge. Food safety must be an imperative of quality.

- The role of commodity reserves as an instrument of agrarian policy should be redefined and revived, which regulates the normal functioning of social agrarian reproduction and ensures the constant maintenance of the equilibrium level of production and consumption.

- Entrepreneurship development and multifunctional agriculture should be encouraged, and local economic development should be accelerated through a new concept of regional development. [Pejanović, 2014, 61]

From all the above, it can be concluded that the "corona" crisis will undoubtedly leave huge consequences on the global, but also on individual national economies and activities in which the activity is significantly limited: agriculture, mining, processing industry, construction, trade and traffic. [Institute of Economic Sciences, 2020, 1]

The impact of the crisis on the agrifood sector and food production will be great and will require a number of measures to be taken by the state in order to reduce and overcome its consequences.

\section{Conclusion}

The global crisis caused by the COVID-19 virus pandemic has significant consequences for the entire world economy, and thus for the Serbian economy. The crisis has caused a decline in all macroeconomic aggregates and indicators, and the key consequences of the crisis are illiquidity, falling production and exports, rising unemployment, falling living standards and rising poverty.

The agri-food sector is one of the most crisis-endangered sectors in the Republic of Serbia, and it is already clear that mitigating and overcoming the consequences of the global "crown" crisis will require taking a number of state measures and actions.

In addition to the fiscal measures adopted by the Government of Serbia in order to help entrepreneurs and maintain the liquidity of economic entities, a special support package should be adopted in the coming period, which will be able to ensure their sustainability during and after the COVID-19 pandemic.

Observed in the long run, the development of agriculture in the $\mathrm{Re}^{-}$ public of Serbia should be focused 
Lukic A. et al., Challenges and Problems of Food Producers in the Conditions of the Covid 19 Virus Pandemic

on the modernization and change of the production structure in the direction of greater business efficiency. For the development of the food industry, it is necessary to provide productive investments based on new technologies, with an export orientation and a net foreign exchange effect.

In any case, the state will play a key role in mitigating the negative effects of the crisis, and the speed of overcoming the crisis will depend, above all, on the quality of institutions and the success of economic stimulus measures determined by the state's ability to formulate and implement consistent economic policy at all levels.

\section{Reference}

Barjaktarović Labović, S. (2018). Public health significance of food safety in relation to knowledge, attitudes and behavior of employees in catering facilities, Kragujevac, Faculty of Medical Sciences

Bošnjak, M. (2011). Global financial and economic crisis and its impact on the economy and finance of Serbia, Belgrade, Ministry of Finance of the Republic of Serbia

World Trade Organization (WTO). (2020). COVID-19 and agricul- ture: a story of resilience, $\mathrm{Ge}^{-}$ neva

Ernst \& Young. (2020). COVID-19 Answering challenges: guidelines for entrepreneurs, Belgrade

Institute of Economic Sciences. (2020). "Black Swan" in the economy 2020 - COVID-19, Belgrade

Republican Bureau of Statistics. (2020). Quarterly gross domestic product in the Republic of Serbia, Belgrade

Markovic, M. (2017). The role of the agri-food sector in increasing the exports of the Republic of Serbia, Nis, Faculty of Economics

Madžar, L. (2014). Significance and export potential of the economy of the Republic of Serbia with special reference to the state of livestock. Novi Sad, School of Business, No. 2/2014, Business School of Vocational Studies in Novi Sad, p. 124 - 140.

Republican Bureau of Statistics. (2020). Monthly statistical bulletin, 01/2020, Belgrade

Mikanović, F. \& Kolar, M. (2020). Measures to combat the economic consequences of the COVID-19 pandemic - Review and comparative analysis, Belgrade, Center for International Public Policy 
Pejanović, R. (2011). Agrarian crises, Novi Sad, Annals of scientific papers of the Faculty of Agriculture, Faculty of Agriculture, Vol. 35, No. 1, p. 5 - 16.

Pejanović, R. (2014). Development problems and priorities of agriculture in the Republic of Serbia. Novi Sad, Proceedings of the conference Performance and Development Possibilities of the Agrarian Industry in AP Vojvodina: A Contribution to the $\mathrm{Re}^{-}$ gional Strategy for Improving the Agrarian Business, Faculty of Agriculture, p. 29 - 66.

${ }^{1}$ https://orcid.org/0000-0002-4922-2937
Government of Republic of Serbia. (2014). Agriculture and Rural Development Strategy of the Republic of Serbia for the period 2014 - 2024, Belgrade

Topić, R. \& Spasojević, B. (2016). Contemporary aspects of the relationship between agriculture and rural development, Bijeljina, Economics, Vol. 4, no. 2, p. 95 112.

Torero Cullen, M. (2020).COVID-19 and the risk to food supply chains: How to respond?, Rome, Food and Agriculture Organization of United Nations 


\section{IZAZOVI I PROBLEMI PROIZVOĐAČA HRANE U USLOVIMA PANDEMIJE KOVID-19}

\section{Aleksandar Lukić1, Dragan Bulatović ${ }^{2}$, Dalibor Misirača ${ }^{3}$ \\ 123 Akademija za poslovnu ekonomiju, Čačak}

Korespondencija: aleksandarlukic.info@gmail.com ${ }^{1}$

Rezime: Trenutna pandemija virusa COVID-19 izazvaće velike posledice po ukupnu svetsku ekonomiju. Globalna pandemija zahteva globalni odgovor i već je jasno da ce kreatori ekonomske politike morati da primene značajne fiskalne, monetarne i socijalne mere kako bi pomogle pogođenom stanovništvu i ekonomiji. U okviru mera podrške privredi, fokus treba usmeriti na podršci sektorima koji su najviše pogođeni. Poljoprivredno-prehrambeni sektor jedan je od najugroženijih sektora privrede i upravo su iz tog razloga predmet ovog rada izazovi i problemi proizvođača hrane u uslovima pandemije.

Ključne reči: pandemija, COVID-19, proizvodnja hrane, ekonomska kriza, mere ekonomske politike. 